\title{
Law Commission, Intermediated Securities Call for evidence (August 2019)
}

Dr Ewan McGaughey ${ }^{1}$

1. The Law Commission's consultation comes at a crucial time, on two incredibly important questions. Who gets the votes in our economy? And are the votes in the economy managed accountably, as is necessary in a democratic society?

2. Before answering the consultation questions, and with due respect to the superb background paper given by the Law Commission, it is necessary to outline the market structure, its problems, and solutions.

3. There are four important facts about international investment:

- if their shares were combined, the top three US asset managers (BlackRock, State Street, Vanguard) would be the largest shareholder in 438 out of the S\&P 500, and 40\% of all US companies. ${ }^{2}$ The 'big three' also own major stakes in most UK companies (below).

- asset managers invest negligible resources on voting: in 2016, BlackRock employed 20 people for engagement and voting in 14,000 companies, Vanguard 15 people for 13,000 companies, and State Street under 10 people for 9,000 companies. ${ }^{3}$ These employees themselves take directions from a smaller group of fund managers. Thus, under 50 people dominate the votes of the US economy.

- a similar situation holds in most European countries, even when banks rather than asset managers dominate. For instance, the top three banks in Germany (Deutsche Bank, Commerzbank, and now Unicredit) probably exercise around $60 \%$ of all shareholder voting rights. ${ }^{4}$

- in the UK, the Office for National Statistics does not record the true concentration of voting power. But in major UK companies, North American, European or UK asset managers and banks are the major registered shareholders.

4. Here are the top ten major holders in six ‘blue chip' FTSE 100 companies: ${ }^{5}$

\footnotetext{
Senior Lecturer, School of Law, King's College, London. Research Associate, Centre for Business Research, University of Cambridge. Please contact at ewan.mcgaughey@kcl.ac.uk. Key publications related to this consultation include: E McGaughey, 'Does Corporate Governance Exclude the Ultimate Investor?' (2016) 16(1) Journal of Corporate Law Studies 221 (also on SSRN, summarised on the Oxford Business Law Blog). E McGaughey, 'Democracy in America at work: the history of labor's vote in corporate governance' (2019) 42 Seattle University Law Review 697, 714-716 (on growth of stock markets) and 740-745 (on modern developments) summarised on the Harvard Corporate Law Blog under section (3). E McGaughey, Participation in Corporate Governance (PhD thesis 2014) ch 6.

2 EA Posner, FS Morton and EG Weyl, 'Proposal to limit the anti-competitive power of institutional investors' (2017) 81 Antitrust Law Journal 1, 2. LA Bebchuk, A Cohen and S Hirst, 'The Agency Problems of Institutional Investors' (2017) 31(3) Journal of Economic Perspectives 89, 92, Table 1, state that the largest five shareholders (mostly mutuals) owned an average $20.8 \%$ of the top-twenty corporations.

3 S Krouse, D Benoit and T McGinty, 'Meet the New Corporate Power Brokers: Passive Investors' (October 24, 2016) Wall Street Journal

4 Deutsche Bundesbank, Statistische Sonderveröffentlichung $9(\underline{2005})$ 32, showing that banks as deposit holders cast over $60 \%$ of votes on company shares from 1984 to 2004, when statistics were discontinued. There was no meaningful legal change since. Source: www.MarketScreener.com as stated on 30 October 2018. In the FTSE100 these are placed (2) HSBC, (3) BP, (13) Vodafone, (19) Sky, (25) Tesco, and (41) SSE.
} 


\begin{tabular}{lrl}
\multicolumn{1}{c}{ HSBC plc } & Shares & $\%$ \\
Major holders & 1253254972 & $6.29 \%$ \\
Ping An Asset Mgt Co., Ltd & 704654217 & $3.54 \%$ \\
BlackRock Inv Mgt (UK) Ltd & 483732164 & $2.43 \%$ \\
The Vanguard Group, Inc. & 435107189 & $2.18 \%$ \\
Legal \& General Inv Mgt Ltd & 368994000 & $1.85 \%$ \\
Norges Bank Inv Mgt & 195820030 & $0.98 \%$ \\
SSgA Funds Mgt, Inc. & 195473551 & $0.98 \%$ \\
BlackRock Advs (UK) Ltd & 189329417 & $0.95 \%$ \\
Aberdeen Asset Invs Ltd & 164914930 & $0.83 \%$ \\
Standard Life Invs Ltd & 149252357 & $0.75 \%$ \\
Aviva Investors Global Serv Ltd & &
\end{tabular}

$20.78 \%$

\section{SSE plc \\ Major holders}

Capital Research \& Mgt Co.

Causeway Capital Mgt LLC

UBS Ltd (Market Maker)

Mondrian Inv Partners Ltd

Invesco Asset Mgt Ltd

The Vanguard Group, Inc.

Legal \& General Inv Mgt Ltd

Norges Bank Inv Mgt

BlackRock Inv Mgt (UK) Ltd

SSgA Funds Mgt, Inc.

$\quad$ Sky plc
Major holders
UBS AG (Inv Mgt)
HSBC Global Asset Mgt (UK) Ltd
BlackRock Inv Mgt (UK) Ltd
The Vanguard Group, Inc.
Norges Bank Inv Mgt
Legal \& General Inv Mgt Ltd
BNP Paribas Asset Mgt France SAS
1832 Asset Mgt LP
Abbey National Treasury Serv Plc

After September 2018 takeover... Comcast Corp.

$\begin{array}{lc}\text { Shares } & \text { \% } \\ 51416557 & 2.99 \% \\ 51398615 & 2.99 \% \\ 37977139 & 2.21 \% \\ 32886502 & 1.91 \% \\ 23411457 & 1.36 \% \\ 17923940 & 1.04 \% \\ 17632490 & 1.03 \% \\ 17073217 & 0.99 \% \\ 16204787 & 0.94 \% \\ & \mathbf{1 5 . 4 6 \%}\end{array}$

$169125264498.40 \%$

\begin{tabular}{lcc}
\multicolumn{1}{c}{ BP plc } & & \\
Major holders & Shares & $\%$ \\
BlackRock Inv Mgt (UK) Ltd & 746987626 & $3.72 \%$ \\
Norges Bank Inv Mgt & 457621000 & $2.28 \%$ \\
The Vanguard Group, Inc. & 448483622 & $2.24 \%$ \\
Legal \& General Inv Mgt Ltd & 417030805 & $2.08 \%$ \\
Invesco Asset Mgt Ltd & 276578037 & $1.38 \%$ \\
M\&G Inv Mgt Ltd & 265052750 & $1.32 \%$ \\
SAFE Inv Co. Ltd & 252479000 & $1.26 \%$ \\
Aberdeen Asset Invs Ltd & 223937497 & $1.12 \%$ \\
Capital Research \& Mgt Co. & 214534898 & $1.07 \%$ \\
Standard Life Invs Ltd & 186963323 & $0.93 \%$ \\
& & $\mathbf{1 7 . 4 0 \%}$
\end{tabular}

$17.40 \%$

$\begin{array}{ll}\text { Shares } & \% \\ 93517080 & 9.11 \% \\ 46731000 & 4.55 \% \\ 36287337 & 3.54 \% \\ 32673000 & 3.18 \% \\ 28896231 & 2.82 \% \\ 25490000 & 2.48 \% \\ 24919000 & 2.43 \% \\ 24737000 & 2.41 \% \\ 21066596 & 2.05 \% \\ 15249000 & 1.49 \% \\ & 34.06 \%\end{array}$

Vodafone Group Plc

Major holder

BlackRock Inv Mgt (UK) Ltd $715704102 \quad 2.68 \%$

Norges Bank Inv Mgt $\quad 628914000 \quad 2.35 \%$

Legal \& General Inv Mgt Ltd $606412021 \quad 2.27 \%$

The Vanguard Group, Inc. $\quad 605753058 \quad 2.27 \%$

Standard Life Invs Ltd $\quad 402897432 \quad 1.51 \%$

Capital Research \& Mgt Co. 383878719 1.44\%

Aberdeen Asset Invs Ltd $\quad 329316448 \quad 1.23 \%$

SSgA Funds Mgt, Inc. $\quad 316533091 \quad 1.18 \%$

BlackRock Advs (UK) Ltd $\quad 286601262 \quad 1.07 \%$

State St Global Advs Ltd $\quad 272803261 \quad 1.02 \%$

$17.02 \%$

Tesco plc

\section{Major holders}

Norges Bank Inv Mgt

Artisan Partners LP

Mondrian Inv Partners Ltd

Schroder Inv Mgt Ltd

Majedie Asset Mgt Ltd

GIC Pte Ltd (Inv Mgt)

The Vanguard Group, Inc.

Magellan Asset Mgt Ltd

BlackRock Inv Mgt (UK) Ltd

State St Global Advs Ltd

$\begin{array}{cc}\text { Shares } & \% \\ 391473927 & 4.00 \% \\ 379897335 & 3.88 \% \\ 346145881 & 3.53 \% \\ 337925490 & 3.45 \% \\ 317668216 & 3.24 \% \\ 291715568 & 2.98 \% \\ 282909714 & 2.89 \% \\ 278707559 & 2.85 \% \\ 270022857 & 2.76 \% \\ 226090808 & 2.31 \% \\ & \mathbf{3 1 . 8 9 \%}\end{array}$

$31.89 \%$

5. In this sample, the top ten shareholders have combined stakes of between 15 and 35 per cent of companies, and the same firms repeat: BlackRock, Vanguard, State Street (SSgA) and Invesco are major US firms. Legal \& General, Aberdeen Asset Management, Abbey National, Standard Life, M\&G and Schroders are major UK firms. Norges Bank is the Norwegian sovereign wealth and pension fund. UBS is a Swiss bank, BNP Paribas is a French bank, and so on.

6. It follows that asset managers and banks dominate the votes in the UK economy. They do this with 'other people's money. ${ }^{6}$ This money usually comes from people saving for retirement, in pension funds, life insurance policies (which are usually a functional equivalent to pensions), and mutual funds (including open-ended investment companies, unit trusts, etc).

7. The chart below shows the change in UK share ownership. The three most dramatic shifts reflect:

${ }^{6}$ cf A Smith, The Wealth of Nations (1776) Book V, ch 1, \$107. LD Brandeis, Other People's Money (1914) 
- (1) de-individualisation and institutionalisation of shareholding and wealth (blue)

- (2) decline in workers' wealth with reduced collective bargaining for good pensions (green) and,

- (3) globalisation (red).

However, the label of 'ownership' must be taken with a pinch of salt because often funds delegate investments to others. Methodology changes after 2008 mean that the statistical picture became very unclear, but also does not help for understanding voting. Statistics on 'ownership' are inadequate, as they largely rely on self-reporting by an asset management industry that is opaque. So, whoever is said to 'own' shares, an asset manager or bank invariably casts votes - with 'other people's money'.

UK share ownership 1963 to 2008

Office for National Statistics, Share Ownership Survey (2008) Table A

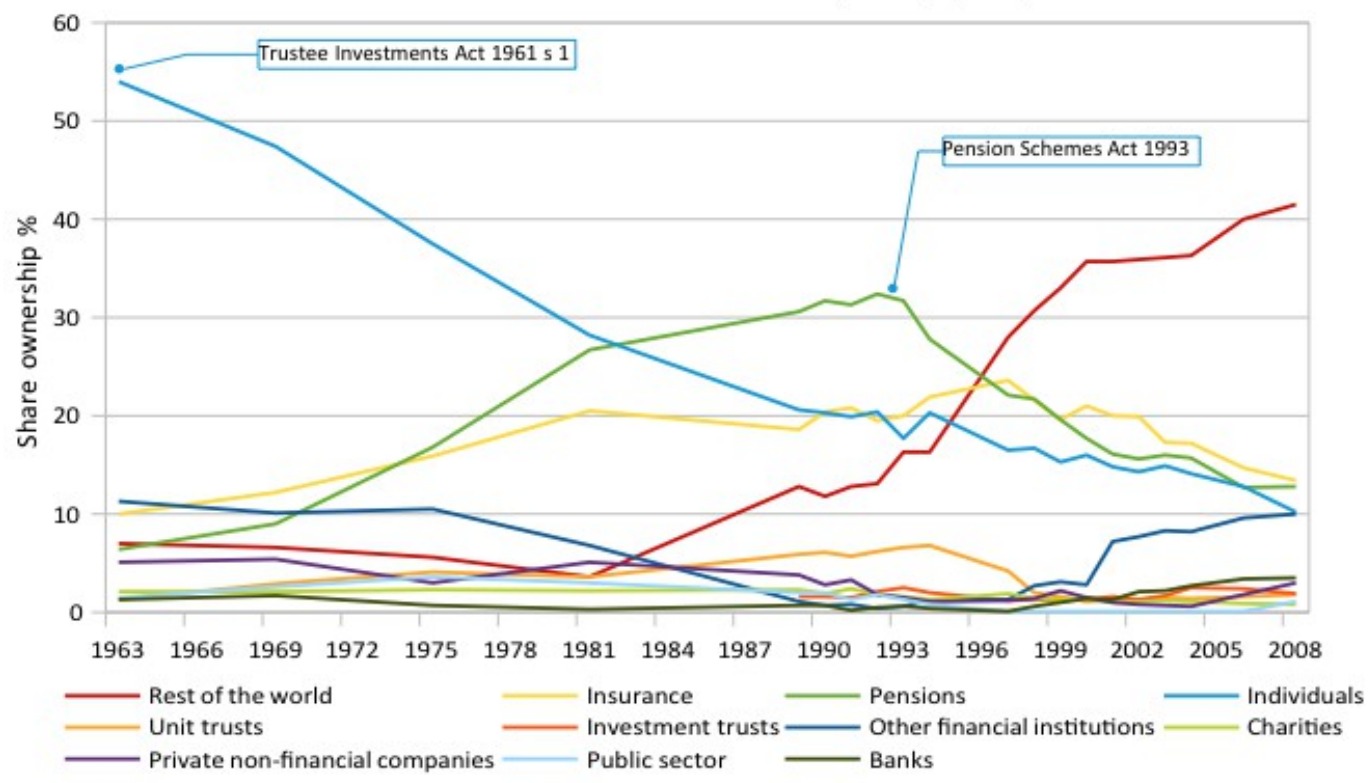

8. Most countries have either asset manager-dominated systems or bank dominated systems of shareholding. The UK has an asset manager-dominated system, because there is a minimum state pension, and so people must put away significant savings in occupational or private pensions, and therefore ultimately invest in the stock market. Countries with bank-dominated systems tend to have income-linked state pensions. ${ }^{7}$ As a guide for portfolio investment, around $70 \%$ of international direct investment in the UK is from the EU or North America, ${ }^{8}$ so regulation abroad affects the quality of accountability at home.

9. Financial intermediaries routinely vote with management, oppose more equal wage scales, oppose resolutions to stop discrimination, oppose attempts to restrain political lobbying, and oppose resolutions to combat climate damage. ${ }^{9}$

McGaughey (2019) 42 Seattle University Law Review 697, 715 see the scatter chart and accompanying text in section II.B. eg Office for National Statistics, UK foreign direct investment, trends and analysis (July 2019) 4

S Hirst, 'Social Responsibility Resolutions' (2018) 43 Journal of Corporation Law 217, 224-227, showing tables of resolutions and the voting record of support on political spending disclosure and carbon emission disclosure. 
10. In the US it has been found that concentrated asset management has led to rising consumer prices, ${ }^{10} \mathrm{a}$ fact described as 'the major new antitrust [or competition law] challenge of our time'. ${ }^{11}$

11. In the UK, there is not yet empirical work on the effects of monopolisation by asset managers on consumer markets. But there is empirical work that shows there is effectively no competition in the provision of investment services and voting rights. The Association of Member Nominated Trustees has shown that virtually every asset manager refuses to follow voting instructions on how their pension fund members' money should be voted when it is in pooled funds. ${ }^{12}$

12. The reason that asset managers should be strictly bound to voting instructions by their clients is that the money does not belong to asset managers. It belongs to the fund beneficiaries, who elect their representatives, or appoint trustees through independent trade unions. Nobody elects asset managers.

13. The reason that asset managers are refusing to follow the voting instructions of pension funds is that asset managers have different preferences. Examples of instructions in the AMNT voting policy include: ${ }^{13}$

- requiring an Environmental Sustainability Committee on every company board (E1)

- introducing and disclosing emission reduction targets (E4)

- ensuring at least a quarter representation of women on boards (S4)

- paying a living wage to all workers and ending zero hours contracts (S6)

- voting against pay policy if directors are paid over 100 times the average worker (G19)

14. The reasons asset managers give for not following instructions have typically been that it is (1) too costly, and (2) too technically difficult to cast split votes in pooled funds. But justifications have changed frequently. Asset managers only appear to be able to cast votes in line with their own preferences.

15. It is not enough to only place a duty on asset managers to follow client instructions, and leave them to exercise votes of other clients who do not send instructions. In such a situation, through apathy, few votes may be cast and the financial intermediary will hoover up the remainder. This is the position in Germany, where banks exercise around $60 \%$ of voting rights. The right of banks to exercise votes in their own name came from bank cartel practices in the 1920s, solidified in a cartel agreement of $1930,{ }^{14}$ and this was codified in the Public Companies Act 1937 (Aktiengesetz 1937 \$114, now Aktiengesetz 1965 \$135). The

\footnotetext{
$10 \mathrm{~J}$ Azar, MC Schmalz and I Tecu, 'Anti-Competitive Effects of Common Ownership' (2016) Ross School of Business Paper No. 1235

11 EA Posner, FS Morton and EG Weyl, 'Proposal to limit the anti-competitive power of institutional investors' (2017) 81 Antitrust Law Journal 1, 2.

2 AMNT review into fund managers' voting policies and practices (May 2019) 20-22.

The Red Lines: Voting Instructions (2016)

4 Centralverband des deutschen Bank- und Bankiergewerbes (1930) BankA 1930-31, 116. McGaughey (2014) ch 6(2)(c)-(d).
} 
1937 Act was drafted under the fascist dictatorship with a view to maintain banker control. ${ }^{15}$ German law has not yet resolved this.

16. Many countries are prohibiting banks or asset managers voting on other people's money, unless they are voting strictly in accordance with instructions or a general voting policy determined by accountale representatives of the true investor. These are two examples of current or proposed laws:

- Switzerland banned banks voting, except in accordance with instructions from pension funds, in $2013^{16}$

- the United States banned broker-dealer voting in the Dodd-Frank Act of 2010 \$957. This followed a well known executive pay scandal at Walt Disney. ${ }^{17}$ A proposal was made by the Bernie Sanders 2020 campaign for US President to extend this ban to all asset managers, unless they are following instructions. ${ }^{18}$ Similar proposals are likely to be made by Democratic Party Senators.

17. In the UK, there is no specific regulation, but there are general principles of common law and equity. The leading cases establish the following principles:

- where company shares are held on trust, and in absence of any specific agreement, a fiduciary must follow the voting instructions of the beneficiary: Butt v Kelson [1952] Ch 197, per Romer LJ. ${ }^{19}$

- no fiduciary may put themselves in a position where there is a possibility of a conflict of interest, in the eyes of a reasonable person: Boardman v Phipps [1966] UKHL 2, at 33, per Lord Upjohn. ${ }^{20}$

18. The principle that no fiduciary may have conflicts of interest is crucial, because UK asset managers (1) currently exercise shareholder voting rights in companies, and (2) also sell financial products to those same companies. This is self-dealing. This poses systemic conflicts of interest. Asset managers have been using their power since the 1970s to inflate demand for their own products and dismantle large pensions funds that could take investment in-house. ${ }^{21}$ It follows that on ordinary principles of law and equity, asset managers should be banned from exercising votes without instructions from their clients.

15 JCD Zahn, Economic Leadership and Contractual Ethics in the New Corporate Law or Wirtschaftsfiuhrertum und Vertragsethik im Neuen Aktienrecht (1934) 93, 'Democracy of capital will disappear just like it did in politics.' 'Die Demokratie des Kapitals wird ebenso verschwinden wie die politische.' See McGaughey (2014) ch 6(2)(d).

16 See the Regulation Against Excessive Compensation at Listed Companies 2013 or Verordnung gegen übermässige Vergütungen bei börsenkotierten Aktiengesellschaften 2013.

17 EB Walter, 'Regulating Broker-Dealers and Investment Advisers: Demarcation or Harmonization?' (2009) 35(1) Journal of Corporation Law 1

18 Corporate Accountability and Democracy (2019) berniesanders.com under the 'Shareholder Democracy' header.

19 [1952] Ch 197, 205, 'The right of a beneficiary, or of the beneficiaries if they are united, is to compel the trustees to use their voting power in the best interests of the trust estate even to the extent, if need be and if the voting power is sufficiently large, of altering the articles of association.' Lord Evershed MR and Birkett LJ agreed. See E McGaughey, 'Does Corporate Governance Exclude the Ultimate Investor?’ (2016) 16(1) Journal of Corporate Law Studies 221, 225, also on SSRN.

20 Lord Upjohn was dissenting but not on this point. It has been reflected in the Companies Act 2006 section 175(4)(a).

21 e.g. J Rifkin and R Barber, The North Will Rise Again: Pensions, Politics and Power in the 1980s (1978) 114-116 record an early example, summarised in McGaughey (2019) on 'Firestone'. In the UK, the prohibition is activated with a mere possible, not an actual conflict of interest, since the South Sea Bubble and the disgrace of Lord Macclesfield LC. See Keech v Sandford [1726] EWHC J76. 


\section{It is desirable that the Law Commission recommends that principles of common law and equity are codified into law, to stop asset managers illegitimately voting on other people's money.}

Giving such an opinion may also swiftly resolve the problem without need for legislation, or litigation.

20. The Law Commission could also helpfully refer the issues of asset manager practices to the Competition and Markets Authority, in order to halt the collective abuse of a dominant position over shareholder voting rights. It should further be investigated whether there has been any collusion over asset manager voting practices, and appropriate penalties should be imposed on any cartel. This possibility must be taken seriously given the extraordinary uniformity of virtually all asset managers refusing to follow voting instructions.

21. In light of the foregoing, the answers to the consultation questions are as follows.

Question 1. Do you consider that it is difficult for ultimate investors to exercise their voting rights? If so: (1) Do you have examples, or specific evidence, of difficulties experienced by ultimate investors in exercising their voting rights? (2) What could be done to solve these problems?

Yes. Through standard form contracts, financial intermediaries routinely deny the representatives of the ultimate investors the exercise of voting rights. Examples are the flat refusal encountered by the Association of Member Nominated Trustees since 2016 (para 11 above).

Another example is among High Street broker-dealers. A recent Barclays' standard form contract said this: 'If you ask us to vote as proxy for you, we may refuse or agree on payment of a fee. ${ }^{22}$ This appears to violate the rule that regulated entities should perform duties (namely, vote according to instructions) without charging fees: Financial Conduct Authority Handbook, COBS 2.3.1R.

These problems are solved by prohibiting financial intermediaries from voting, unless they are following instructions (paras 18-19 above). To facilitate voting, it is also necessary for financial intermediaries to make modest investments in electronic voting infrastructure to handle instructions.

Question 2. Are there particular systems or models of bolding intermediated securities which could better facilitate the passing back of direct rights for ultimate investors? If so, what are the current obstacles to the use of such systems?

There does not appear to be any need for 'passing back of direct rights' as opposed to following instructions. Votes are already being cast by financial intermediaries, but these votes are at odds with the

22 Barclays Wealth Management and Investment, Barclays Terms: Your Agreement With Us (June 2015) Section B, Part 5, 7.15, Part 7, 3.2. 
preferences of the ultimate investors.

The main obstacles to following instructions are asset managers themselves. They will hold onto power over other people's money with all kinds of exotic argument, because votes are necessary to inflate their businesses, and charge more fees, at the expense of everyone else's savings (para 18).

Question 3. Do you consider that the type of vote affects the extent to which ultimate investors can exercise voting rights? If so, do you have examples, or specific evidence, of this issue?

Asset managers appear to be particularly opposed to voting in accordance with instructions on issues that threaten their common interests with company boards or managements (para 13). These include:

- (1) stopping the escalation of executive pay, or paying workers a living wage - because asset manager pay is itself inflated out of proportion, ${ }^{23}$

- (2) stopping the gender pay gap or promoting gender equality - because asset managers continue to have serious problems with institutional sexism, ${ }^{24}$

- (3) stopping climate damage by companies - because asset managers have investments in greenhouse gas emitters that are destroying the ecosphere (even if it is ceasing to be profitable). ${ }^{25}$

In essence, workers' and pensioners' own retirement savings are being used against them.

Question 4. Do you consider that it is difficult for ultimate investors to obtain confirmation that their votes have been received and/ or counted? If so: (1) What is the impact of this? (2) Do you have examples, or specific evidence, of difficulties experienced by ultimate investors in confirming that their votes have been received and/ or counted? (3) What could be done to solve these problems?

As in question 1, Barclays' standard contract exemplifies High Street banks giving no guarantee that votes will ever be counted.

By contrast - and practically speaking, a vastly greater amount of money - the key issue is that asset managers are (unlawfully) refusing to follow voting instructions at all in relation to pension funds.

It may be that a large amount of time in this consultation is spent looking at voting in relation investors or clients that are not elected through the vote or who are not appointed by trade unions. However, the most important experiences are of those who lack bargaining power in the market, or whose social interests diverge from financial intermediaries in the City.

23 e.g. C Flood, 'Sector reins in awards but CEO remuneration still faces scrutiny' (1 September 2019) Financial Times, 'BlackRock chief executive Larry Fink took a pay cut last year — but the head of the world's largest asset manager still earned more than double any rival mutual fund company boss.'

24 e.g. M Marriage and A Mooney, 'Sexism still rife in asset management' (15 August 2016) Financial Times, 'The habit of male bonding at strip bars is pervasive. One could argue that, strictly speaking, these are extracurricular activities. But when they routinely happen after a desk dinner, or after the closing dinner of a conference, it becomes clear that the camaraderie affects professional relationships in the office as well.' These are the words of a male employee.

25 e.g. A Mooney, 'BlackRock lambasted over wasteful fossil fuel investments' (1 August 2019) Financial Times 
Question 5. Do you consider that the rules and practical arrangements relating to the timing of voting affect the ability of ultimate investors to vote? If so: (1) Do you have examples, or specific evidence, of these problems? (2) What could be done to solve these problems?

The practicalities of mass voting mean that it will usually be undesirable for anyone to cast votes on specific issues (of which there will be millions) rather than to ensure policies are in place that cover general preferences for all issues. In this way, timing is less important than the general practice of the industry.

Question 6. Do you consider that there are aspects of proxy voting which may affect the rights of ultimate investors in the context of an intermediated securities chain? If so: (1) Do you have examples, or specific evidence, of these problems? (2) What could be done to solve these problems?

The workings of a standard voting chain exemplify why it presents no technical or practical problems for asset managers or banks to follow instructions. Throughout the chain funds are often pooled, and votes are often split in pooled funds.

Question 7. Do you consider that the headcount test in section 899 of the Companies Act 2006 has the potential to cause problems in the context of intermediated securities? In what way? If so: (1) Do you have examples, or specific evidence, of problems arising out of the application of section 899 of the Companies Act 2006 to intermediated securities? (2) What could be done to solve these problems?

The headcount test represents a practice from a time long ago when companies used to be more democratic, and started with a presumption of 'one person, one vote', and where people stood 'upon an equal foot', per Lord Hardwicke CJ, Stoughton v Reynolds (1735) 93 ER 1023.

It is often thought that today the shift has been towards a paradigm of 'one share, one vote'. The reality is that a group of unaccountable middlemen are dominating most companies, without paying a penny for the shares they control.

The simple solution to the specific problems of head counting, where they arise, is of course that any member should be able to demand an electronic poll of votes if a headcount is not satisfactory.

\section{Questions 8 to 23 and 25. Nothing to add.}

Question 24. What other jurisdictions should we consider and why?

Two good jurisdictions to consider are Switzerland, and the experience of the United States with the Dodd-Frank Act of $2010 \$ 957$ (para 16). These give models on voting regulation, and a principle 
adaptable to every financial intermediary: follow voting instructions from the representatives of the ultimate investor, and do not vote otherwise. Germany is also worth considering on the basis of why requiring instructions are followed (without banning uninstructed votes) is not sufficient (para 15). ${ }^{26}$

Question 26. What are the benefits - financial or otherwise - of the current system of intermediation? What are the costs or disadvantages - are there any problems beyond those we have highlighted above?

As outlined in paragraphs 9-11 and 18, there are very considerable benefits of the current system of intermediation for financial intermediaries, and tremendous costs to everyone else. These are,

- the damage to competition in investment, and in consumer product and service markets,

- the damage to the environment from complacency over climate damage,

- the escalating inequality between boardrooms, bankers, and asset managers, and everyone else,

- the threat to democracy from the extraordinary concentration of power in the hands of a tiny group of asset managers and banks.

Questions 27 and 28. What could be the benefits - financial or otherwise - of ensuring the availability of rights and remedies to the ultimate investor in an intermediated securities chain? What could be the costs - financial or otherwise - of ensuring the availability of rights and remedies to the ultimate investor in an intermediated securities chain?

The 'availability of rights and remedies to the ultimate investor' is important, but also rights and remedies for the elected or accountable representatives of the ultimate investor. Beyond the example of an individual retail investor wishing to exercise voting rights through her High Street bank, representative voting structures serve as an efficient mechanism to aggregate preferences and determine general policies. This is what the Pensions Act 2004 sections 241-243 do by creating 'member nominated trustees'. It is also what trade unions did by collectively bargaining for union trustees that would manage their members' retirement savings. There are analogous rules in company law for mutual funds. It could be highly desirable to codify representative voting structures, to ensure minimum standards of democracy in capital, regardless of the legal form. ${ }^{27}$

However, when pension funds or trustees delegate investments to other financial intermediaries they should not be deemed to have abdicated their fiduciary duty to act in the best interests of their beneficiaries. Trustees must also be capable of fulfilling their duties by sending instructions. The interests of beneficiaries will only be served by following voting preferences arrived at through representative voting. Because asset managers are not elected, their interests directly conflict with the clients from whom they make fees. They cannot be allowed to continue taking votes from other people's money.

\footnotetext{
26 For historical background, see E McGaughey, Participation in Corporate Governance (2014) ch 6

27 A summary of those legal forms is in E McGaughey, 'Does Corporate Governance Exclude the Ultimate Investor?' (2016) 16(1) Journal of Corporate Law Studies 221
} 
